\title{
Transport externalities of bus stations produced by Greenhouse Gas (GHG)
}

\author{
Córdova-Suárez, $M^{1 *}$; Barreno-Ávila, $E^{2}$; Villacrés-Cevallos, $P^{3}$; Ruíz-Robalino, $O^{1}$ \\ ${ }^{1}$ Universidad Técnica de Ambato, Facultad de Ciencia e Ingeniería en Alimentos, Ambato, Ecuador \\ ${ }^{2}$ Universidad Técnica de Ambato, Facultad de Ingeniería Mecánica, Ambato, Ecuador \\ ${ }^{3}$ Universidad Nacional de Chimborazo, Facultad de Ingeniería, Riobamba, Ecuador
}

\begin{abstract}
It is established that the interprovincial transportation in bus terminals of the Cities such as Ambato, Riobamba, Salcedo, Latacunga and Guaranda have contributed to the build-up of external costs of Greenhouse Gases (GHG) The climate change costs are calculated by multiplying the carbon emissions by the cost factor. To quantify the GHG emissions, this study has taken into account of both the direct and indirect sources of the Greenhouse Gas Protocol (GHG), as well as the ISO 14064.1: 2006 standard. In view thereof, it was found that the 11 bus terminals of the five cities, namely Latacunga, Riobamba Salcedo, Ambato, Guaranda-which accounts for around 3225 buses, had accounted for the emissions of 25,746.8 $\mathrm{tCO}_{2}$ eq, 37,404.6 $\mathrm{tCO}_{2} \mathrm{eq}, 8,762.7 \mathrm{tCO}_{2} \mathrm{eq}, 92,364.9 \mathrm{tCO}_{2} \mathrm{eq}, 31,990.3 \mathrm{tCO}_{2} \mathrm{eq}$, respectively. Simply, the average load of such pollution produced per vehicle was $60.8 \mathrm{tCO}_{2} \mathrm{eq}$. and the total emissions were $196,269.3 \mathrm{tCO}_{2} \mathrm{eq}$ with an estimated GHG contamination cost of $€ 27,477,702$ per year.
\end{abstract}

\section{Background}

Externalities are created when the final product production, the expected good or service and the associated pollutant emissions, produces a negative effect on another agent without receiving any compensation [1]. In other words, this produces a loss of social wellbeing due to lack of contaminant-free air.

In Latin America, direct climate change transformations have been observed whereby, the temperature is increasing at the rate of average of $0,1^{\circ} \mathrm{C}$ every ten years because of the Greenhouse gas emissions (GHG) [2]. This is forcing countries to take measures by prioritizing social sectors so that problems can be mitigated; issues such premature deaths of more than two million people per year [3] and also the costs generated by non-pollution efforts

Current bus transportation needs require the use of heavy vehicles that move continuously that run on the diesel engines.[4] The use of this type of vehicle has produced quite an impact on the environment by emitting pollutants into the air. [5]. The transportation sector has a direct impact on the accelerated growth of greenhouse gas (GHG) emissions, which cause climate change. [6].

The interprovincial bus stations infrastructures have met the requirements to satisfy the needs of the embarkation and disembarkation passengers [7]. Yet, these activities have accumulated GHG emissions from direct and indirect sources polluting the environment as a result. Once the emissions are quantified, thereby identifying the most relevant sources can the areas of emission reduction and efficiency increase can be prioritized.
The climate change externalities' costs can be calculated by multiplying the emissions of carbon dioxide equivalent in tons of one year $\left(\mathrm{tCO}_{2} \mathrm{eq}\right)$ by a cost factor. First, it is necessary to determine (CO2) carbon dioxide emissions, (NOx) nitrogen oxides and (CH4) methane according to the Greenhouse Gas Protocol (GHG) guidelines and the ISO 14064.1: 2006 standard.

In market economies where the economic resources' scarcity is not clearly shown, the direct quantification of these externalities is estimated by policymaker asking for a value to be paid in favour of environmental improvement or a compensation [8]. The estimation methodology for the non-contamination cost calculation which is used to consider the costs of goods through its used or unused economic value, and the determination of the externality economic value has become an essential part of the socioenvironmental economy in business activities [9].

As the Ecuadorian highlands bus stations agglomerate a significant number of buses, people and resource consumption resulting in the generation of GHG its pollution costs will, therefore, be analysed.

\section{Methodology}

The methodology is illustrated in the flow chart in figure 1 .

\subsection{Greenhouse Gas (GHG) measuring equipment}

The Bacharach ECA 450 analyzer was used to measure the efficiency of combustion gases and environmental emissions, (see figure 2) following the methodology of Boruta, Imiolek

\footnotetext{
*Corresponding author: ma.cordova@uta.edu.ec
} 
(Boruta et al., 2013). This equipment measures and displays the oxygen percentage $(\mathrm{O} 2)$ and the concentration of carbon monoxide $(\mathrm{CO})$, nitric oxide $(\mathrm{NO})$, nitrogen dioxide $\left(\mathrm{NO}_{2}\right)$ and sulfur dioxide $\left(\mathrm{SO}_{2}\right)$ of flue gases.

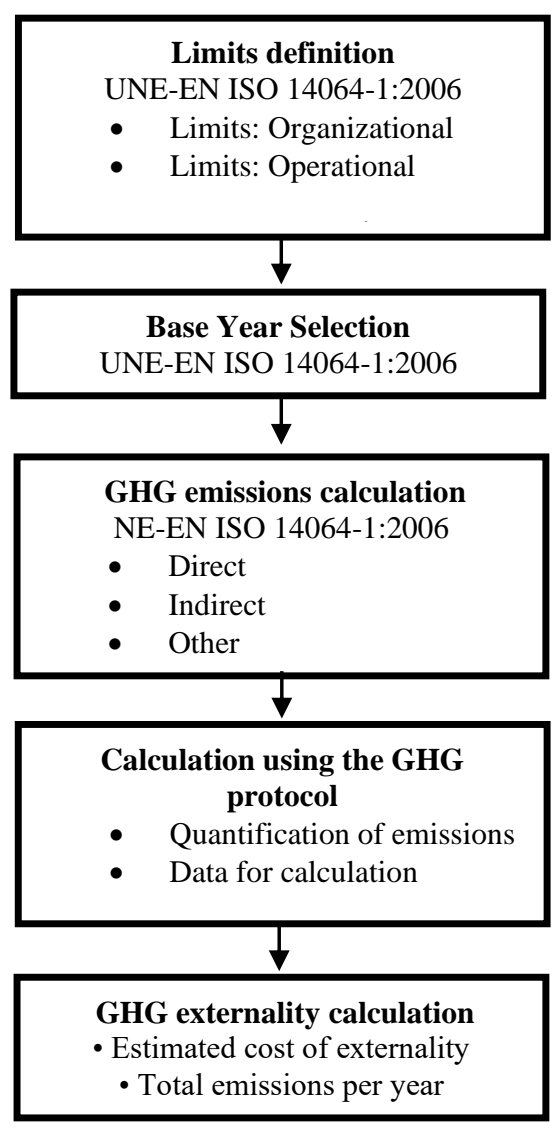

Fig. 1. Bus stations' GHG externalities assessment flowchart.

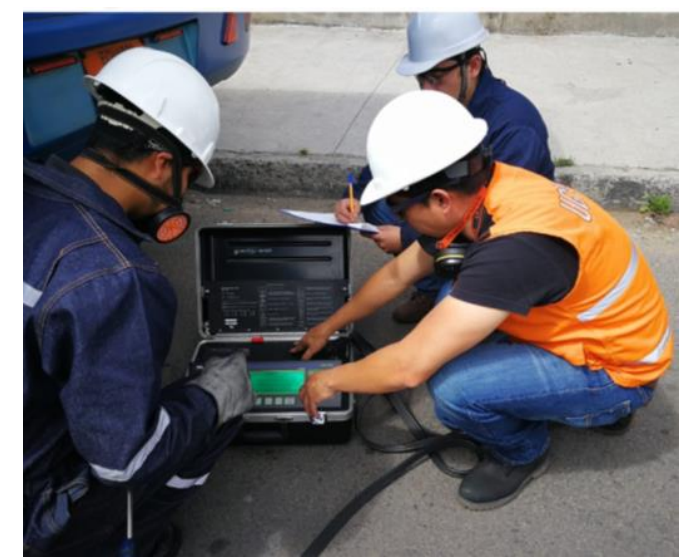

Fig. 2. GHG Bachacach ECA 450 measuring equipment.

\subsection{Sample Size Determination}

A stratified sample was computed [10] with proportional fixation to separate the pollution into exclusive segments, in which the homogeneity and minimum variance are analyzed. For this investigation, a sample of 3225 buses with a $95 \%$ confidence level is considered. Later, the sample was then classified according to the European Emission Standard by considering the manufacture year. See table 1 .
Table 1. European emission standard application range

\begin{tabular}{ccc}
\hline Tier & $\begin{array}{c}\text { Standard Implementation } \\
\text { Date }\end{array}$ & $\begin{array}{c}\text { Vehicle } \\
\text { Manufacturing } \\
\text { Year }\end{array}$ \\
\hline Euro I & December 31, 1992 & $1994-2000$ \\
Euro II & January 1, 1997 & $2001-2010$ \\
Euro III & January 1, 2002 & Since 2011 \\
Euro IV & January 1, 2007 & No aplica \\
Euro V & January 1, 2011 & No aplica \\
Euro VI & September 1, 2015 & No aplica \\
\hline Note: The first three categories are considered homologated in Ecuador \\
according to the National Transit Agency. This is an adaptation from [11]
\end{tabular}

\subsection{Calculation of GHG emissions}

To begin with, according to the EURO standard (TOTAL, 2015), the land transport classification by city has three categories: EURO I, EURO II, EURO III. For the gas emissions quantification, (Galarza Baldeón, 2016) -1: 2006 It will carry out the following actions: define limits, select the base year, identify the emissions and finally quantify the emissions using the Greenhouse Gases Protocol (GHG).

\subsubsection{Calculation of direct GHG emissions (scope I)}

GHG emissions which generated by vehicles in the bus stations are considered. [12].

\subsubsection{Calculation of indirect GHG emissions (scope II)}

Under this scope, GHG emissions generated by bus stations' energy consumption are established. The data collection method is used for scope II emissions [13] according to figure 3 .

\subsubsection{Calculation of indirect GHG emissions (scope III)}

With regard to this area, those GHG generation sources which do not belong to this case study, (such as the interprovincial transport buses occupying the bus station), are considered. [14]. To proceed, the main data such as the manufacture year, service operator brand and name are vital.

Following the quantification methodology (see figure 4) and according to the GHG protocol, it is necessary to know: the type of fuel, the amount of fuel consumed and price.

\subsection{Calculation of emission factors.}

$\mathrm{CO}_{2}$ carbon dioxide emission factor

It starts by determining the $\% \mathrm{CO}_{2}$ and applying equation 1 .

$$
\left[\mathrm{CO}_{2}\right]=\left(\% \mathrm{CO}_{2} * \mathrm{DA} * \mathrm{CS}\right) /(\mathrm{TC} * 100)
$$

$\left[\mathrm{CO}_{2}\right]=\mathrm{CO} 2$ concentration $(\mathrm{kg} /$ year $)$

$\mathrm{DA}=$ Air density $(\mathrm{kg} / \mathrm{L})$

$\mathrm{CS}=$ Probe flow $(\mathrm{L} / \mathrm{min})$

$\mathrm{TC}=$ Combustion time (day)

Afterwards, the emission factor is calculated utilizing the application described in equation 2 


$$
F E\left(\mathrm{CO}_{2}\right)=\frac{\left[\mathrm{CO}_{2}\right]}{D A}
$$

$\mathrm{FE}\left(\mathrm{CO}_{2}\right)=$ emission factor de $\mathrm{CO}_{2}\left(\mathrm{kgCO}_{2} / \mathrm{TJ}\right)$

\section{$\mathrm{DA}=$ activity data $(\mathrm{TJ})$}

The air density was calculated considering an uncertainty of $+-1^{\circ} \mathrm{C}$ as ambient temperature and $+-0,1 \mathrm{hPa}$ as atmospheric pressure .[15]

\section{Nitrous Oxide Emission Factor $\mathrm{N}_{2} \mathrm{O}$}

It is calculated using the stoichiometric equation of $\mathrm{N} 2 \mathrm{O}$ formation [16]:

$$
2 \mathrm{NO}+\mathrm{CO}=\mathrm{N}_{2} \mathrm{O}+\mathrm{CO}_{2}
$$

With equation 4, the final $\mathrm{N} 2 \mathrm{O}$ (N2Of) was determined as follows:

$$
\left[\mathrm{N}_{2} \mathrm{O}\right]_{f}=\frac{\left[\mathrm{NO}_{\text {medición }}\right] *\left[\mathrm{~N}_{2} \mathrm{O}\right]}{[\mathrm{NO}] * 1000}
$$

Donde:

$\left[\mathrm{NO}_{\text {medición }}\right]=\mathrm{NO}$ concentration of the measurement $(\mathrm{g} / \mathrm{year})$ $\left[\mathrm{N}_{2} \mathrm{O}\right]=$ mass of $\mathrm{N}_{2} \mathrm{O}(\mathrm{g} /$ year $)$

$\left[\mathrm{N}_{2} \mathrm{O}\right] \mathrm{f}=$ mass of final $\mathrm{N} 2 \mathrm{O}(\mathrm{Kg} /$ year $)$

Next, the emission factor of $\mathrm{N} 2 \mathrm{O}$ is determined using equation 5.

$$
F E\left(N_{2} O\right)=\frac{\left[N_{2} O\right]_{f}}{n A}
$$

Where:

FE $\left(\mathrm{N}_{2} \mathrm{O}\right)=$ emission factor de $\mathrm{N}_{2} \mathrm{O}(\mathrm{kg} / \mathrm{TJ})$

$\left[\mathrm{N}_{2} \mathrm{O}\right]=$ mass of $\mathrm{N} 2 \mathrm{O}$ (g/year)

$\mathrm{DA}=$ activity data $(\mathrm{TJ})$

\subsection{GHG emission calculation}

The GHG emission considering both direct and indirect sources is calculated with equation (6):

$$
E G E I=\frac{D A \times F E}{1000}
$$

Where:

$\mathrm{EGEI}=\mathrm{GHG}$ emission $\left(\mathrm{tCO}_{2}\right)$

$\mathrm{DA}=$ activity data $(\mathrm{TJ})$

Considering the potential of global warming [17] The total emissions in tons of $\mathrm{CO} 2$ equivalent to a year $\mathrm{CO} 2$-eq are determined with the equation (7).

$$
E \mathrm{CO}_{2-e q}=\mathrm{DE} * P C G
$$

Where:

$\mathrm{ECO}_{2 \text {-eq }}=\mathrm{GHG}$ emission in $\left(\mathrm{tCO}_{2 \text {-eq }}\right)$

$\mathrm{DE}=$ emission data of $\mathrm{CO}_{2}, \mathrm{~N}_{2} \mathrm{O}$ and $\mathrm{CH}_{4}(\mathrm{TJ})$

$\mathrm{PCG}=$ Global warming potential at 100 years $\left(\mathrm{tCO}_{2 \text {-eq }}\right)$

\subsection{Calculation of the externality cost due to GHG emissions}

From the recommended values to the calculation of the global warming cost, the most commonly used methods recommend to consider the values between $1 € / \mathrm{tCO}_{2}$ and 140 $€ / \mathrm{tCO}_{2}$. Although the most used methodology considers the avoided costs, the estimation hypotheses are very sensitive. In fact, there are already many considerations such as the discount rate, the potential for impact, the function of the damage, the pace of climate change, the impacts on the ecosystem. In other words, for the consideration of the damage aggregation, the shadow cost will be considered [18], not only because its value does not give intervals, but also this is the most updated data.

Lastly, the shadow pricing methodology is used to estimate a comparison point among the costs obtained in the countries of the European Community, which uses the value of $140 € / \mathrm{tCO}_{2}[19]$

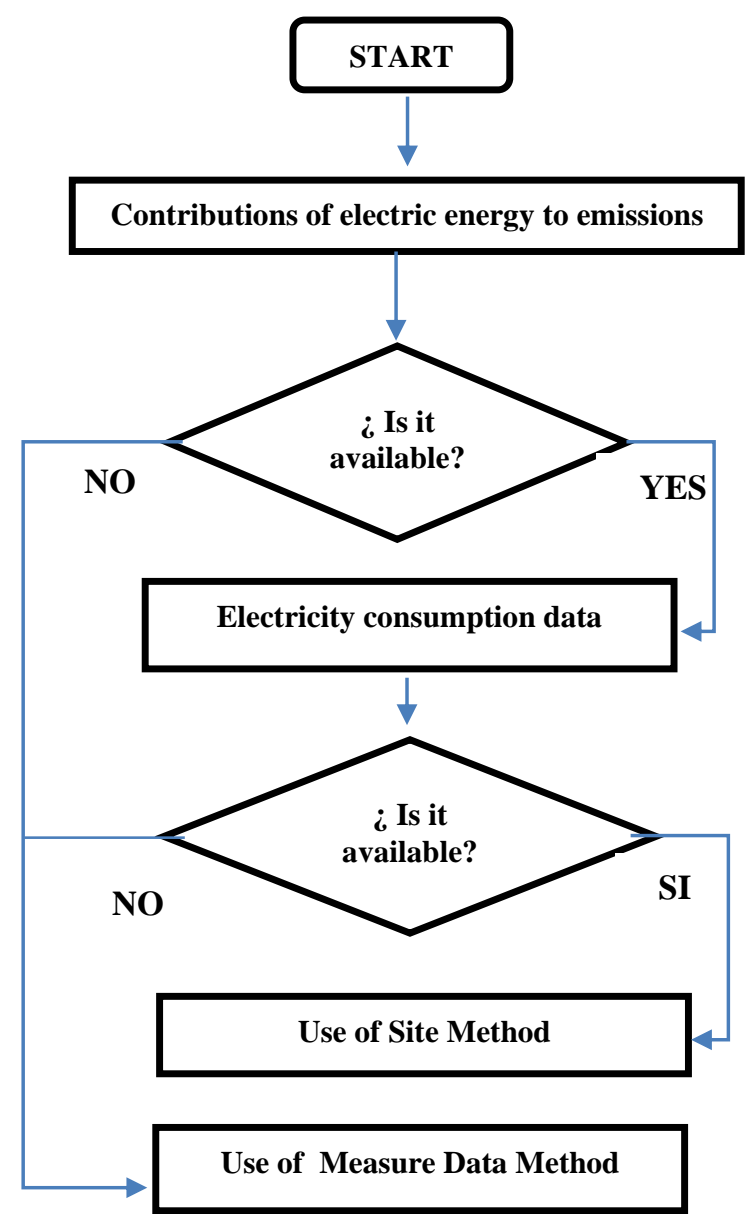

Fig. 3. Flujograma para realizar el cálculo de las emisiones del alcance II con el GHG protocol. 


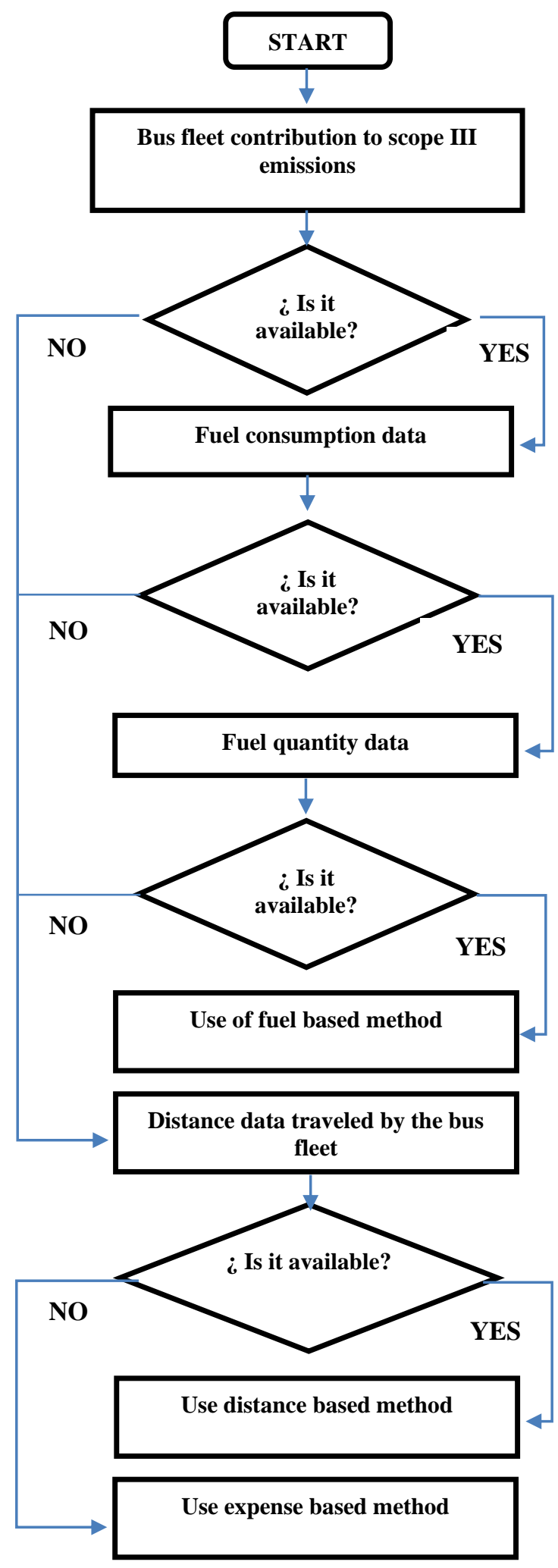

Fig. 4. Scope III emissions calculation flowchart according to the GHG protocol. Adaptation from [11].

\section{Results and discussion}

\subsection{Results of emission factors.}

Table 2 shows the total emission factor by city.
Table 2. Emission factors by city

\begin{tabular}{|c|c|c|}
\hline City & $\begin{array}{c}\text { Emission Factor } \\
(\mathrm{Kg} / \mathrm{TJ})\end{array}$ & $\begin{array}{c}\text { Emission Factor IPCC* } \\
(\mathrm{Kg} / \mathrm{TJ})\end{array}$ \\
\hline Latacunga & 78793,66 & \\
\hline Riobamba & 57690,13 & 74100 \\
\hline Salcedo & 89842,21 & \\
\hline Ambato & 78131,53 & \\
\hline Guaranda & 49172,97 & \\
\hline
\end{tabular}

Note: *IPCC=Intergovernmental Panel on climate change

Although the city of Salcedo did not have a large number of vehicles compared with the other cities in the study, it has, however, recorded a higher emission factor value.

\subsection{Results of emission factors by scope}

Table 3 illustrates the $\mathrm{CO}_{2}$ emissions in tons. $\left(\mathrm{tCO}_{2}\right)$ by cities. It is considered $851,4 \mathrm{Kg} / \mathrm{m}^{3}$ as the diesel density and 0,04 $\mathrm{TJ} / \mathrm{t}$ as the calorific value of diesel [20].

Table 3. Emission factors by scope

\begin{tabular}{|c|c|c|c|}
\hline City & $\begin{array}{c}\text { Scope I } \\
\left(\mathrm{tCO}_{2}\right)\end{array}$ & $\begin{array}{c}\text { Scope } \\
\text { II } \\
\left(\mathrm{tCO}_{2}\right)\end{array}$ & $\begin{array}{c}\text { Scope III } \\
\left(\mathrm{tCO}_{2}\right)\end{array}$ \\
\hline Latacunga & 0,0 & 23,3 & $25.723,6$ \\
\hline Riobamba & 0,0 & 16,2 & $37.388,2$ \\
\hline Salcedo & 0,0 & 33,8 & $8.728,9$ \\
\hline Ambato & 71,7 & 133,4 & $92.159,7$ \\
\hline Guaranda & 0,0 & 23,1 & $31.967,2$ \\
\hline
\end{tabular}

Note: In the city of Ambato, the values in Scope I are shown because the bus station in question has its own vehicles. $36 / 5000$.

For scope II the value taken was $0.5062 \mathrm{tCO}_{2} / \mathrm{MW}$.h.

\subsection{Results of total emissions by category}

In table 4 is presented the $\mathrm{CO}_{2}$ emissions in $\mathrm{tCO}_{2 \text {-eq }}$ from each city.

Table 4. Results of total emissions by category

\begin{tabular}{|c|c|c|c|}
\hline City & $\begin{array}{c}\text { EURO 1 } \\
\text { (number of } \\
\text { busses) }\end{array}$ & $\begin{array}{c}\text { EURO 2 } \\
\text { (number of } \\
\text { busses) }\end{array}$ & $\begin{array}{c}\text { EURO 3 } \\
\text { (number of busses) }\end{array}$ \\
\hline Latacunga & 33 & 322 & 99 \\
\hline Riobamba & 99 & 400 & 210 \\
\hline Salcedo & 10 & 56 & 37 \\
\hline Ambato & 51 & 845 & 608 \\
\hline Guaranda & 0 & 110 & 335 \\
\hline
\end{tabular}

In table 5 is presented the $\mathrm{CO}_{2}$ emissions in $\mathrm{tCO}_{2 \text {-eq }}$ from each city mentioned in this study 
Table 5. shows the $\mathrm{CO}_{2}$ emissions in $\mathrm{tCO}_{2}$-eq from each city.

\begin{tabular}{|c|c|c|c|}
\hline City & $\begin{array}{c}\text { EURO 1 } \\
\left(\mathbf{t C O}_{\text {2-eq }}\right)\end{array}$ & $\begin{array}{c}\text { EURO 2 } \\
\left(\mathbf{t C O}_{\text {2-eq }}\right)\end{array}$ & $\begin{array}{c}\text { EURO 3 } \\
\left(\mathbf{t C O}_{\text {2-eq }}\right)\end{array}$ \\
\hline Latacunga & $2.176,1$ & $18.250,3$ & $5.297,1$ \\
\hline Riobamba & $5.445,7$ & $20.908,1$ & $11.034,5$ \\
\hline Salcedo & 730,6 & $4.866,1$ & $3.132,2$ \\
\hline Ambato & $3.918,9$ & $52.622,8$ & $35.716,9$ \\
\hline Guaranda & 0,0 & $8.277,7$ & $23.689,4$ \\
\hline
\end{tabular}

Note: As The Global Warming Percentage values are considered 1, 25, 298 for $\mathrm{CO}_{2}, \mathrm{~N}_{2} \mathrm{O}, \mathrm{CH}_{4}$, respectively. [21]

\subsection{Results of total GHG emissions}

Table 6 illustrates the $\mathrm{CO}_{2}$ emissions in $\mathrm{tCO}_{2 \text {-eq }}$ for each city.

Table 6. Total GHG emissions

\begin{tabular}{|c|c|}
\hline City & $\begin{array}{c}\text { Total emissions } \\
\mathrm{tCO}_{2-\mathrm{eq}}\end{array}$ \\
\hline Latacunga & $25.746,8$ \\
\hline Riobamba & $37.404,6$ \\
\hline Salcedo & $8.762,7$ \\
\hline Ambato & $92.364,9$ \\
\hline Guaranda & $31.990,3$ \\
\hline
\end{tabular}

\subsection{Cost results for GHG in bus stations}

In table 7, the costs for GHGs are presented from 5 cities' bus stations within the central area of Ecuador. The data required to estimate each of the scopes is requested by ISO 14064.1: 2006ISO 14064.1:2006. They were calculated based on the information provided by the Decentralized Autonomous Governments (GADS) from each of the cities.

Table 7. Costs considering GHG externalities at bus stations within the central region of Ecuador.

\begin{tabular}{|c|c|}
\hline City & $\begin{array}{c}\text { GHG cost } \\
(€ / \text { year })\end{array}$ \\
\hline Latacunga & $3.604 .552,0$ \\
\hline Riobamba & $5.236 .644,0$ \\
\hline Salcedo & $1.226 .778,0$ \\
\hline Ambato & $12.931 .086,0$ \\
\hline Guaranda & $4.478 .642,0$ \\
\hline
\end{tabular}

Note: The shadow cost used is $140 € / \mathrm{tCO}_{2}$.

\section{Conclusions}

From the results by scope of 5 cities having 11 bus stations, it is observed ranges between $99.99 \%$ to $99.62 \%$ of $\mathrm{tCO}_{2 \text {-eq }}$ global emissions for Scope III.

Nonetheless, there are some other modern factors which might increase this emission factor; as can be seen in old cars or busses, which are not functioning according to international standards. Moreover, altitude can also be another factor that increases CO2-eq. In the central area of Ecuador, the global GHG emissions reports was 196.269,3
$\left(\mathrm{tCO}_{2 \text {-eq }}\right)$. The said value was higher in interprovincial buses from Ambato and Riobamba, accounting for $99.99 \%$. Similarly, the previous result is compared to the amount of $\left(\mathrm{tCO}_{2 \text {-eq }}\right)$ generated by electricity consume of approximately $220,480.1$ Ecuadorian individual houses per year.

The GHG pollution cost is $27.477 .702 €$ per year.

The 2018 external costs of the bus stations are estimated to represent 30,2 \% of Gross Domestic Product (GDP) of Ecuador. Surprisingly, this figure exceeds in $10.2 \%$ in similar studies that were conducted in Euskadi - Europe [22]. The externality total cost data is required to compare with the European GDP percentage.

\section{References}

1. R. Perman, Y. Ma, J. McGilvray, and M. Common, "Natural resource and environmental economics," Harlow: Pearson, (2003).

2. N. E. P. Bellido, "Cambio climático, pobreza y sostenibilidad," EHQUIDAD. Revis. Inter. de Polí. de Biene. y Trab. So.l, pp. 81-116,( 2017).

3. R. A. Rohde and R. A. Muller, "Air pollution in China: mapping of concentrations and sources," PloS one, vol. 10, p. e0135749, (2015).

4. H. C. Frey, N. M. Rouphail, H. Zhai, T. L. Farias, and G. A. Gonçalves, "Comparing real-world fuel consumption for diesel- and hydrogen-fueled transit buses and implication for emissions," Transportation Research Part D: Transport and Environment, vol. 12, pp. 281-291, 2007.

5. C. Wang, Z. Ye, Y. Yu, and W. Gong, "Estimation of bus emission models for different fuel types of buses under real conditions," Science of the Total Environment, vol. 640-641, pp. 965-972, 2018.

6. J. A. Barbero and R. R. Tornquist, "Transporte y cambio climático: hacia un desarrollo sostenible y de bajo carbono," Revi. Trans. y Territo., pp. 8-26, (2012).

7. L. Flores Fernández, "Terminales terrestres interprovinciales."

8. D. W. Pearce and R. K. Turner, Economía de los recursos naturales y del medio ambienteEconomics of natural resources and the environment: Celeste Ediciones: Colegio de Economistas de Madrid, 1995.

9. D. Azqueta, ", McGraw Hill Profesional, Madrid, 420 p," Biblioteca Introducción a la Economía Ambiental, 2002.

10. G. K. F. Tso and J. Guan, "A multilevel regression approach to understand effects of environment indicators and household features on residential energy consumption," Energy, vol. 66, pp. 722-731, (2014).

11. M. A. León Silva, "Cálculo de las emisiones de efecto invernadero en el terminal terrestre de Salcedo como base para futuros proyectos de Mecanismo de Desarrollo Limpio (MDL)," Universidad Técnica de Ambato. Facultad de Ciencia e Ingeniería en Alimentos. Carrera de Ingeniería Bioquímica,( 2018).

12. C. E. Galarza Baldeón, "Estimación de la huella de carbono según la ISO 14064-1 alcance 1 y 2 de una 
planta productora de concreto premezclado y prefabricado," 2016.

13. S. Finnegan, S. Sharples, T. Johnston, and M. Fulton, "The carbon impact of a UK safari park - Application of the GHG protocol using measured energy data," Energy, vol. 153, pp. 256-264, (2018).

14. E. G. Hertwich and R. Wood, "The growing importance of scope 3 greenhouse gas emissions from industry," Environmental Research Letters, vol. 13, 2018.

15. Dolzhno, "Cálculo de la densidad del aire.," (2017).

16. T. E. Lipman and M. A. Delucchi, "Emissions of nitrous oxide and methane from conventional and alternative fuel motor vehicles," Climatic Change, vol. 53, pp. 477516, (2002).

17. R. Price, S. Thornton, and S. Nelson, "The social cost of carbon and the shadow price of carbon: what they are, and how to use them in economic appraisal in the UK," (2007).

18. M. Maibach, C. Schreyer, D. Sutter, H. Van Essen, B. Boon, R. Smokers, et al., "Handbook on estimation of external costs in the transport sector," CE Delft, 2008.

19. INFRAS/IWW. (2004). External Costs of Transport. Update Study, Zurich/Karlsruhe, UIC.

20. MAE. (2012). Factor de emisión de CO2 del Sistema Nacional Interconectado del Ecuador. Available: www.ambiente.gob.ec

21. GHG. Global Warming Potential Values (AR5). Greenhouse Gas Protocol [Online]. Available: http://ghgprotocol.org/sites/default/files/ghgp/GlobalWarming-PotentialValues\%20(Feb\%2016\%202016).pdf

22. D. H. Ramos, "La estimación de costes externos del transporte: una aplicación para Euskadi," Ekonomiaz: Revista vasca de economía, pp. 240-267, (2004). 